\title{
PENGARUH STRES KERJA DAN PENGEMBANGAN KARIR TERHADAP PRESTASI KERJA KARYAWAN PADA PT. JASA MARGA (PERSERO) TBK CABANG BELMERA
}

\author{
MOHD. HEIKAL
}

Dosen pada Fakultas Ekonomi dan Bisnis, Universitas Malikussaleh, Lhokseumawe

Job performance is as a result of work has been accomplished person from his behavior in carrying out work activities. There are several factors that affect the achievement of which stress and career development. Stress may contribute incorrectly or damaging the work performance. In simple terms this means that the stress potential to disrupt the implementation of the work. In addition to job stress, career development is also a matter that affects job performance. Career development needs to be done in a planned and sustainable. With the opening of the career opportunities are accompanied by a realistic career goals and reasonable could lead to a satisfactory performance. Both of these need to be considered by PT. Jasa Marga (Persero) Tbk Branch Belmera in terms of improving performance. This study aimed to determine the effect of work stress on work performance, to determine the effect of job stress and career development to job performance. Data collection techniques in this study using a study of documentation, interviews and using a questionnaire. The processed data was analyzed qualitatively and quantitatively.

Keywords: Job Stress, Career Development, Job Performance 


\section{LATAR BELAKANG}

Salah satu tujuan perusahaan adalah ingin menjadikan perusahaan tersebut sebagai perusahaan yang dapat menjaga keberlangsunganya, tentunya dengan mampu bersaing sampai waktu yang lama. Untuk dapat menjaga keberlangsungannya dan mempunyai daya saing, perusahaan harus dapat memanfaatkan sumber daya organisasi yang ada, salah satunya adalah sumber daya manusia.

Sumber daya manusia merupakan kunci pokok yang harus diperhatikan dengan segala kebutuhannya dalam sebuah perusahaan. Tentunya dalam hal ini sumber daya manusia yang memiliki prestasi. Sumber daya manusia yang memiliki prestasi kerja akan mampu menjaga kesetabilan perusahaan yang nantinya dapat membawa perusahaan untuk meraih tujuanya.

Apalagi dalam dunia bisnis yang berkembang semakin pesat saat ini serta perkembangan pengetahuan dan teknologi yang semakin canggih maka hal itu akan membawa perubahan pola kehidupan karyawan. Perubahan tersebut mengakibatkan tuntutan yang lebih tinggi terhadap setiap karyawan untuk lebih meningkatkan prestasi kerja mereka.

Pentingnya prestasi kerja seorang karyawan untuk mengetahui di mana terdapat kelebihankelebihan maupun kekurangan-kekurangan yang dimilikinya, bagi mereka yang memiliki prestasi kerja yang tinggi, memungkinkan dirinya untuk diberikan promosi, sebaliknya, karyawan yang prestasinya rendah dapat diperbaiki dengan memindahkan kejabatan sesuai dengan kecakapannya ataupun melalui pendidikan dan latihan dalam rangka pengembangan karyawan (Hasibuan 2013, hal. 90).

Prestasi kerja merupakan hasil kerja yang telah dicapai seseorang dari tingkah laku kerjanya dalam melaksanakan aktivitas kerja (Sutrisno 2012, hal. 151). Ada banyak cara yang dapat ditempuh oleh perusahaan untuk meningkatkan prestasi kerja karyawan sehingga menjadi tenaga kerja yang berkualitas dimana tentang tinggi rendahnya prestasi kerja seorang karyawan dapat diperoleh melalui proses yang panjang yaitu dengan menilai prestasi kerja karyawan.
Ada beberapa faktor yang menyebabkan karyawan mempunyai motif prestasi, salah satunya adalah stres kerja (T. Hani Handoko 2014, hal 193). Stres dapat membantu atau merusak prestasi kerja karyawan tergantung seberapa besar tingkat stres tersebut.

Stres merupakan respon tubuh yang sifatnya nonspesifik terhadap setiap tuntutan beban atasnya. Misalnya bagaimana respons tubuh seseorang manakala yang bersangkutan mengalami beban pekerjaan yang berlebihan. Bila ia sanggup mengatasinya artinya tidak ada gangguan pada fungsi organ tubuh, maka dikatakan yang bersangkutan tidak mengalami stres. Tetapi sebaliknya bila ia mengalami gangguan pada satu atau lebih organ tubuh sehingga yang bersangkutan tidak lagi dapat menjalankan fungsi pekerjaannya dengan baik, maka ia disebut mengalami stres (Hawari 2013, hal. 17).

Stres merupakan suatu masalah yang pasti akan dihadapi oleh setiap orang dalam bekerja. Maka dari itu stres harus diatasi baik oleh karyawan sendiri (tanpa bantuan orang lain) maupun dibantu pihak lain seperti para spesialis yang disediakan perusahaan dimana karyawan bekerja.

Stres dapat timbul sebagai akibat tekanan atau ketegangan yang bersumber dari ketidak selarasan antara seseorang dengan lingkungannya. Hampir setiap kondisi pekerjaan bisa menyebabkan stres tergantung pada reaksi karyawan. Stres dapat berperan salah atau merusak prestasi kerja. Secara sederhana hal ini berarti bahwa stres berpotensi untuk mengganggu pelaksanaan kerja.

Selain stres kerja, pengembangan karir juga merupakan hal yang mempengaruhi prestasi kerja. Pengembangan karir perlu dilakukan secara terencana dan berkesinambungan. Dengan terbukanya peluang karir yang disertai oleh suatu tujuan karir yang realistis dan wajar akan dapat menimbulkan suatu prestasi kerja yang memuaskan. Pangkal tolak pengembangan karir seseorang adalah prestasi kerjanya untuk melakukan tugas yang dipercayakan kepadanya (Siagian 2008, hal. 215).

Begitu pula halnya dengan PT. Jasa Marga (Persero) Tbk, Cabang Belmera sangat memperhatikan prestasi kerja karyawannya. Sebagai perusaahan yang bergerak di bidang jasa jalan tol. PT. Jasa Marga (Persero) Tbk, Cabang Belm- 
era sangat mengandalkan sumber daya manusia dalam setiap aktivitas kerjanya. Pentingnya prestasi kerja merupakan modal utama bagi perusahaan untuk mencapai tujuannya. Berdasarkan survey pendahuluan yang dilakukan, dalam satu tahun terakhir ini sumber daya manusia di perusahaan tersebut tentunya dalam hal prestasi kerja sedang mengalami penurunan. Penurunan prestasi kerja karyawan yang disebabkan karna karyawan stres dalam menghadapai pekerjaan. Stres tersebut ditimbulkan karna ketidakjelasan pekerjaan yang dilakukan oleh karyawan sehingga karyawan tidak tepat waktu dalam menyelesaikan pekerjaan. Selain daripada itu karyawan juga tidak memahami pekerjaan yang diberikan. Selain Stres yang menyebabkan prestasi kerja karyawan menurun, pengembangan karir juga menjadi faktor menurunnya prestasi kerja karyawan. Ini terlihat dari tidak adanya peluang berkarir bagi karyawan yang berprestasi dan minimnya pengembangan karir yang disediakan oleh perusahaan.

\section{LANDASAN TEORI}

\section{Pengertian Prestasi kerja}

Prestasi kerja merupakan suatu proses untuk mengukur secara akurat tingkat keefektifitasannya dan keefesiensian dari suatu hasil kerja yang terealisasi dan membandingkan dengan tingkat prestasi yang direncanakan. Maka dari itu setiap pemimpin perlu mempunyai ukuran prestasi kerja bagi setiap karyawannya, agar dalam pengambilan keputusan tidak terjadi masalah. Menurut Hasibuan (2013, hal. 94) Prestasi kerja adalah suatu hasil kerja yang dicapai seseorang dalam melakukan tugas-tugas yang dibebankan kepadanya yang didasarkan kecakapan, pengalaman dan kesunguhan serta waktu.Prestasi kerja merupakan gabungan dari tiga faktor penting, yaitu kemampuan dan minat seorang pekerja, kemampuan dan penerimaan atas penjelasan delegasi tugas, serta peran dan tingkat motivasi seorang pekerja. Semakin tinggi ketiga faktor diatas semakin besarlah prestasi kerja karyawan bersangkutan.

\section{Pengertian Stres kerja}

Karyawan merupakan makhluk sosial yang menjadi kekayaan utama bagi setiap perusahaan.
Mereka menjadi perencana, pelaksana, dan pengendali yang selalu berperan aktif dalam memujudkan tujuan perusahaan.Karyawan menjadi pelaku yang menunjang tercapainya tujuan, mempunyai pikiran, perasaan, dan keinginan yang mempenagruhi sikap-sikapnya terhadap pekerjaannya. Sikap ini akan menetukan prestasi kerja, dedikasi, dan kecintaan terhadap pekerjaan yang di bebankan kepadanya. Sikap-sikap positif harus dbina, sedangkan sikap-sikap negatif hendaknya dihindarkan sedini mungkin salah satunya yaitu stres kerja. Panji Anoraga (2009, hal. 108) menyatakan bahwa secara sederhana stres merupakan suatu bentuk tanggapan seseorang, baik secara fisik maupun mental, terhadap suatu perubahan dilingkungannya yang dirasakan mengganggu dan mengakibatkan dirinya terancam.

\section{Pengertian Pengembangan karir}

Karir merupakan seluruh pekerjaan yang dipegangnya selama ia bekerja. Untuk sebagian orang, pekerjaan/kedudukan tersebut merupakan bagian dari rencananya.Pengembangan karir dimulai dari diri sendiri. Setiap orang harus menerima tanggung jawab pengembangan karirnya sendiri, setelah komitmen dibuat barulah aksi pengembangan karir dilakukan untuk meningkatkan prestasi kerja karyawan tersebut. M Andrew J. Fubrin dalam Mangkunegara (2013, hal. 77) mengemukakan bahwa pengembangan karir adalah aktivitas kepegawaian yang membantu pegawai-pegawai merencanakan karir masa depan mereka di perusahaan agar perusahaan dan pegawai yang bersangkutan dapat mengembangkan diri secara maksimum.

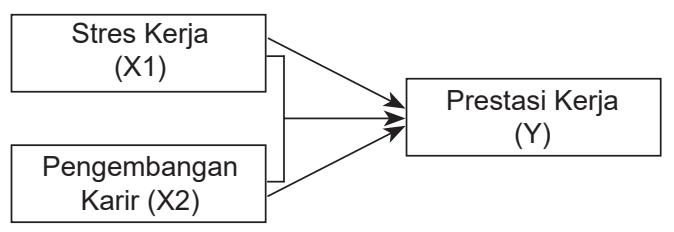

Gambar 1. Paradigma Penelitian

\section{METODOLOGI PENELITIAN}

\section{Pendekatan Penelitian}

Penelitian asosiatif adalah penelitian yang berupaya untuk mengkaji bagaimana suatu vari- 
abel memiliki keterkaitan atau berhubungan dengan variabel lain, atau apakah suatu variabel dipengaruhi oleh variabel lainnya, atau apakah suatu variabel menjadi sebab perubahan variabel lainnya.

\section{Definisi Operasional Variabel}

Definisi operasional yang digunakan dalam penelitian ini adalah sebagai berikut:

1. Variabel Dependen (Variabel Terikat/Y)

Variabel terikat ini merupakan variabel yang dipengaruhi atau yang menjadi akibat, karena adanya variabel bebas. Prestasi kerja karyawan merupakan bagian penting dari seluruh proses kekaryaaan pegawai yang bersangkutan. Pentingnya prestasi kerja yang rasional adalah bagi pegawai yang bersangkutan dan organisasi. Bagi pegawai, prestasi kerja tersebut bermanfaat untuk menentukan tujuan, jalur, rencana dan pengembangan karirnya. Bagi PT. Jasa Marga (persero) Tbk, Cabang Belmera Medan prestasi kerja tersebut sangat penting untuk memiliki sumber daya manusia yang mampu mewujudkan tujuan yang ingin dicapai oleh perusahaan.

2. Variabel Independen (Variabel Bebas)

Variabel bebas merupakan variabel yang mempengaruhi atau menjadi sebab perubahannya atau timbulnya variabel terikat. Variabel yang digunakan dalam penelitian ini adalah sebagai berikut :

\section{a. Stres kerja}

Variabel bebas $\left(\mathrm{X}_{1}\right)$ yang digunakan dalam penelitian ini adalah Stres kerja. Stres kerja adalah kondisi ketegangan yang berpengaruh terhadap emosi, jalan pikiran dan kondisi fisik seseorang yang apabila tidak teratasi akan berpengaruh terhadap prestasi kerja. Dalam penelitian ini ada stres kerja yang dialami karyawan PT. Jasa Marga (Persero) Tbk, Cabang Belmera.

b. Pengembangan karir

Variabel bebas $\left(\mathrm{X}_{2}\right)$ yang digunakan dalam penelitian ini adalah Pengembangan karir. Pengembangan karir merupakan penyusunan jalur karir yang berkaitan dengan urutan-urutan posisi (jabatan) yang mungkin diduduki oleh seorang pegawai mulai dari tingkat terendah hingga tingkatan teratas dalam struktur organisasi. Penelitian ini akan menjelaskan pengembangan karir yang dilakukan PT. Jasa Marga (Persero) Tbk, Cabang
Belmera terhadap karyawan-karyawannya

\section{Teknik Analisis Data}

Metode dalam teknik analisis data yang digunakan dalam penelitian ini adalah analisis data kuantitatif yaitu dengan menguji dan menganalisis data dengan perhitungan angka - angka dan kemudian menarik suatu kesimpulan dari pengujian data tersebut. Analisis data dalam penelitian ini adalah:

\section{Regresi Berganda}

Analisis data dalam penelitian ini menggunakan analisis linear berganda. Dalam penelitian ini terdapat dua variabel independen, yaitu stres kerja dan pengembangan karir, serta satu variabel dependen yaitu prestasi. Adapun rumus linear berganda adalah sebagai berikut :

$$
\boldsymbol{Y}=\boldsymbol{a}+\boldsymbol{\beta}_{I} \boldsymbol{X}_{1}+\boldsymbol{\beta}_{2} \boldsymbol{X}_{2}+\boldsymbol{\varepsilon}
$$

(Sugiyono, 2010, hal. 277)

Dimana:

$\mathrm{Y}=$ Prestasi Kerja

$\mathrm{a}=\mathrm{Y}$ bila $\mathrm{x} 1$, dan $\mathrm{x} 2=0$

$\beta=$ Angka arah koefisien regresi

$\mathrm{x} 1$ = Hasil perhitungan Stres Kerja

x2 = Hasil perhitungan Pengembangan Karir

$\varepsilon=$ Standard error

Secara statistik ketepatan fungsi regresi sampel dalam menafsir aktual dapat diukur dari nilai statistik t, nilai statistik F serta koefisien determinasinya. Suatu perhitungan statistik disebut signifikan secara statistik apabila nilai uji statistiknya berada dalam daerah kritis (daerah dimana $\mathrm{H}_{0}$ ditolak). Sebaliknya disebut tidak signifikan bila nilai uji statistiknya berada dalam daerah dimana $\mathrm{H}_{0}$ diterima.

\section{Uji Asumsi Klasik}

Apabila terjadi penyimpangan dalam pengujian asumsi klasik perlu dilakukan perbaikan terlebih dahulu. Pengujian asumsi klasik tersebut meliputi uji normalitas, uji multikolinearitas dan uji heterokedastisitas.

a. Uji Normalitas

Uji ini digunakan untuk mengetahui apakah model regresi variabel pengganggu atau residual memiliki distribusi normal. Uji normalitas yang 
digunakan dalam penelitian ini yaitu:

- Normal P-P Plot of Regression Standardized Rasidual

Uji ini dapat digunakan untuk melihat model regresi normal atau tidak dengan syarat yaitu apabila data mengikuti garis diagonal dan menyebar disekitar garis diagonal tersebut:

Jika data menyebar disekitar garis diagonal dan mengikuti arah garis diagonal, maka model regresi ini memenuhi asumsi normalitas.

Jika data menyebar jauh dari garis diagonal dan atau tidak mengikuti arah garis, maka model regresi tidak memenuhi asumsi normalitas.

- Kolmogorov Smirnov

Uji ini bertujuan agar dalam penelitian ini dapat mengetahui berdistribusi normal atau tidaknya variabel independen dengan variabel dependen ataupun keduanya. Menurut Juliandi (2013, hal. 175) Uji statistik dapat digunakan untuk menguji apakah residual berdistribusi normal adalah uji statistik non parametrik Kolmogorov Smirnov (K-S) dengan membuat keputusan:

$\mathrm{H}_{0}$ : Data residual berdistribusi normal

$\mathrm{H}_{\mathrm{a}}$ : Data residual tidak berdistribusi normal Maka ketentuan uji Kolmogorov Smirnov ini adalah sebagai berikut :

Asymp Sig (2-tailed) > 0,05 (a- 5\% tingkat signifikan) maka data berdistribusi normal. Asymp Sig (2-tailed) < 0,05 (a- 5\% tingkat signifikan) maka data berdistribusi tidak normal.

\section{b. Uji Multikolinearitas}

Uji ini bertujuan untuk menguji apakah model regresi ditemukan adanya korelasi antar variabel bebas (independen). Model regresi yang baik seharusnya bebas multikolinearitas atau tidak terjadi korelasi diantara variabel independen. Uji multikolinearitas dapat dilihat dari: nilai tolerance dan lawannya, dan Variance Inflation Factor (VIF). Jika nilai tolerance lebih besar dari 0,1 atau nilai VIF lebih kecil dari 10, maka dapat disimpulkan tidak terjadi multikolinearitas pada data yang akan diolah.

c. Uji Heterokedastisitas

Uji ini digunakan agar mengetahui adanya ketidaksamaan varians dari residual satu penga- matan ke pengamatan lain dalam sebuah model regresi. Bentuk pengujian yang digunakan dengan metode informal atau grafik scatterplot, dasar analisis:

- Jika ada pola tertentu, seperti titik - titik yang ada membentuk pola tertentu yang teratur (bergelombang, melebar kemudian menyempit), maka mengindikasikan telah terjadi heterokedastisitas.

- Jika tidak ada pola yang jelas, serta titik - titik menyebar di atas dan di bawah angka nol (0) pada symbu Y, maka tidak terjadi heterokedastisitas.

\section{Uji Secara Parsial (Uji - t)}

Uji statistik t dilakukan untuk menguji apakah variabel bebas (X) secara individual mempunyai hubungan yang signifikan atau tidak terhadap variabel terikat (Y). Untuk menguji signifikasi hubungan, digunakan rumus uji statistik t. Dengan rumus sebagai berikut:

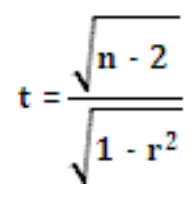

Sugiyono (2010, hal. 250)

Dimana:

$\mathrm{t} \quad=$ nilai hitung

$\mathrm{r}=$ koefisien korelasi

$\mathrm{n}$ = banyaknya pasangan rank

Tahap-tahap :

1. Bentuk pengujian

- $\mathrm{H}_{0}: \mathrm{r}_{\mathrm{s}}=0$, artinya tidak terdapat hubungan signifikan antara variabel bebas $(\mathrm{X})$ dengan variabel terikat (Y).

- $\mathrm{H}_{0:} \mathrm{r}_{\mathrm{s}} \neq 0$, artinya terdapat hubungan signifikan antara variabel bebas $(\mathrm{X})$ dengan variabel terikat (Y).

2. Kriteria pengambilan keputusan

- $\mathrm{H}_{0}$ diterima jika : $-\mathrm{t}_{\text {tabel }} \leq \mathrm{t}_{\text {hitung, }}$ pada $\alpha=5 \%, \mathrm{df}=$ $\mathrm{n}-\mathrm{k}$

- Ha ditolak jika : $\mathrm{t}_{\text {hitung }}>\mathrm{t}_{\text {tabel }}$ atau $-\mathrm{t}_{\text {hitung }}<-\mathrm{t}_{\text {tabel }}$

3. Pengujian hipotesis

- Bila $\mathrm{t}_{\text {hitung }}>\mathrm{t}_{\text {tabel }}$ atau $-\mathrm{t}_{\text {hitung }}<-\mathrm{t}_{\text {tabel }}$, maka H0 ditolak karena adanya korelasi yang signifikan 
antara variabel $\mathrm{x}$ dan $\mathrm{y}$.

- Bila $\mathrm{t}_{\text {hitung }} \leq \mathrm{t}_{\text {tabel }}$ atau $-\mathrm{t}_{\text {hitung }} \geq-\mathrm{t}_{\text {tabel }}$, maka H0 diterima karena tidak adanya korelasi yang signifikan antara variabel $\mathrm{x}$ dan $\mathrm{y}$.

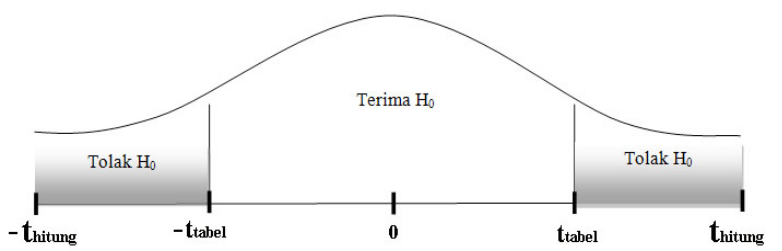

Gambar 2. Kriteria Pengujian Hipotesis Uji t

4. Uji Simultan Signifikan (Uji - F)

Uji - F menunjukkan apakah semua variabel independen atau bebas dimasukkan dalam model, yang mempunyai pengaruh secara bersama - sama terhadap variabel dependen. Untuk pengujiannya dilihat dari nilai struktur modal ( $\mathrm{p}$ value) yang terdapat pada tabel Anova nilai F dari output. Program aplikasi SPSS, dimana jika struktur modal ( $p$ value $)<0,05$ maka secara simultan keseluruhan variabel independen memiliki pengaruh secara bersama - sama pada tingkat signifikan 5\%.

Adapun pengujiannya sebagai berikut:

$\mathrm{H} 0: \beta=0$, artinya variabel independen tidak berpengaruh terhadap variabel dependen.

H0 : $\beta \neq 0$, artinya variabel independen berpengaruh terhadap variabel dependen.

Sugiyono (2009, hal. 192)

Dimana :

$\mathrm{R}=$ Koefisien korelasi ganda

$\mathrm{k}=$ Jumlah variabel independen

$\mathrm{n}=$ Jumlah anggota sampel

Ketentuan :

Bentuk Pengujiannya

$\mathrm{HO}=$ Tidak ada pengaruh antara Stres kerja dan Pengembangan karir terhadap Prestasi kerja .

$\mathrm{Ha}=$ Ada pengaruh antara Stres kerja dan Pegembangan karir terhadap prestasi kerja.

Kriteria Pengujian

Tolak $\mathrm{H}_{0}$ apabila $\mathrm{F}_{\text {hitung }}>\mathrm{F}_{\text {tabel }}$ atau $-\mathrm{F}_{\text {hitung }}<-\mathrm{F}_{\text {tabel }}$ Terima $\mathrm{H}_{0}$ apabila $\mathrm{F}_{\text {hitung }}<\mathrm{F}_{\text {tabel }}$ atau $-\mathrm{F}_{\text {hitung }}>-\mathrm{F}_{\text {tabel }}$ Pengujian Hipotesis

Bila $\mathrm{F}_{\text {hitung }}>\mathrm{F}_{\text {tabel }}$ dan $-\mathrm{F}_{\text {hitung }}<-\mathrm{F}_{\text {tabel }}$ maka $\mathrm{H}_{0}$ ditolak karena adanya korelasi yang signifikan antara variabel X1, X2, X3 dengan $\mathrm{Y}$.

Bila $\mathrm{F}_{\text {hitung }} \leq \mathrm{F}_{\text {tabel }}$ dan $-\mathrm{F}_{\text {hitung }} \geq-\mathrm{F}_{\text {tabel }}$ maka $\mathrm{H}_{0}$ diterima karena tidak adanya korelasi yang signifikan antara variabel X1, X2, X3 dengan Y. Taraf signifikan yang digunakan adalah 5\%, uji dua pihak dan $\mathrm{dk}=\mathrm{n}-\mathrm{k}-1$

Keterangan :

$\mathrm{F}_{\text {hitung }}=$ Hasil perhitungan korelasi Stres kerja dan Pengembangan karir terhadap Prestasi kerja $\mathrm{F}_{\text {tabel }}=$ Nilai $\mathrm{F}$ dalam tabel $\mathrm{F}$ berdasarkan $n$.

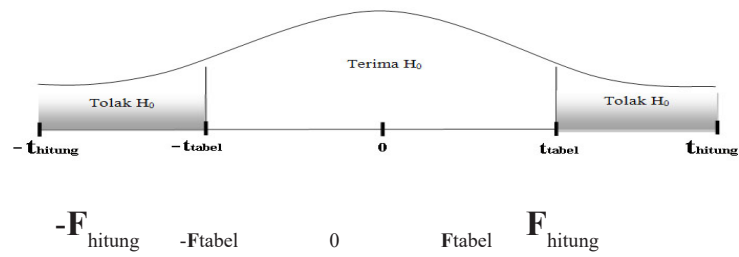

Gambar 3. Kriteria Pengujian Hipotesis Uji F

\section{Koefisien Determinasi (R-Square)}

Koefisien determinasi ini berfungsi untuk mengetahui persentase besarnya pengaruh variabel independen dan variabel dependen yaitu dengan mengkuadratkan koefisien yang ditemukan. Nilai R-Square adalah untuk melihat bagaimana variasi nialai variabel trikat dipengaruhi oleh variasi nilai bebas. Formulasi ini dirumuskan sebagai berikut :

$$
D=R^{2} \times 100 \%
$$

Dimana:

$\mathrm{D}=$ Determinasi

$\mathrm{R}^{2}=$ Nilai Korelasi Berganda

$100 \%=$ Persentase Kontribusi

\section{HASIL PENELITIAN}

Objek penelitian yang digunakan adalah PT. Jasa Marga (persero) Tbk, Cabang Belmera, populasi pada penelitian ini sebanyak 212 orang, dengan menggunakan rumus slovin makan sample yang digunakan sebanyak 106 orang.

1. Variabel Prestasi Kerja (Y)

Berikut ini merupakan deskripsi atau penyajian data dari variabel prestasi kerja yang dirangkum di 
dalam Tabel 1. Dengan demikian, dari kesimpulan jawaban responden terhadap prestasi kerja karyawan dominan menjawab setuju dibandingkan dengan yang lain ini berarti bahwa prestasi kerja karyawan di PT. Jasa Marga (persero) baik.

\section{Variabel Stress Kerja $(X 1)$}

Berikut ini merupakan deskripsi penyajian data berdasarkan jawaban yang dirangkum dalam Tabel 2. Dengan demikan, dari kesimpulan jawaban responden terhadap stres kerja dominan re- sponden menjawab setuju dibandingkan dengan yang lain, ini berarti bahwa karyawan di PT. Jasa

Marga mengalami stres kerja

3. Variabel Pengembangan Karir (X2)

Berikut ini merupakan deskripsi atau penyajian data dari penelitian variabel disiplin kerja yang dirangkum dalam Tabel 3. Dengan demikian, dari kesimpulan jawaban responden dominan menjawab setuju, yang berarti pengembangan karir karyawan di PT. Jasa Marga baik.

Tabel 1

Penyajian Data Mengenai Variabel Prestasi kerja (Y)

\begin{tabular}{|c|c|c|c|c|c|c|c|c|c|c|c|c|}
\hline \multirow{2}{*}{ No. } & \multicolumn{10}{|c|}{} & \multicolumn{10}{|c|}{ Sangat Setuju } & \multicolumn{2}{|c|}{ Setuju } & \multicolumn{2}{|c|}{$\begin{array}{c}\text { Kurang } \\
\text { Setuju }\end{array}$} & $\begin{array}{c}\text { Tidak } \\
\text { Setuju }\end{array}$ & $\begin{array}{c}\text { Sangat Tidak } \\
\text { Setuju }\end{array}$ & \multicolumn{2}{|c|}{ Jumlah } \\
\cline { 2 - 14 } & F & $\%$ & F & $\%$ & F & $\%$ & F & $\%$ & F & $\%$ & F & $\%$ \\
\hline 1 & 13 & $12,3 \%$ & 39 & $36,8 \%$ & 42 & $39,6 \%$ & 10 & $9,4 \%$ & 2 & $1,9 \%$ & 106 & $100 \%$ \\
\hline 2 & 15 & $14,2 \%$ & 43 & $40,6 \%$ & 34 & $32,1 \%$ & 12 & $11,3 \%$ & 2 & $1,9 \%$ & 106 & $100 \%$ \\
\hline 3 & 13 & $12,3 \%$ & 39 & $36,8 \%$ & 42 & $39,6 \%$ & 10 & $9,4 \%$ & 2 & $1,9 \%$ & 106 & $100 \%$ \\
\hline 4 & 3 & $2,8 \%$ & 21 & $19,8 \%$ & 46 & $43,4 \%$ & 23 & $21,7 \%$ & 13 & $12,3 \%$ & 106 & $100 \%$ \\
\hline 5 & 2 & $1,9 \%$ & 32 & $30,2 \%$ & 40 & $37,7 \%$ & 18 & $17,0 \%$ & 14 & $13,2 \%$ & 106 & $100 \%$ \\
\hline 6 & 20 & $18,9 \%$ & 56 & $52,8 \%$ & 27 & $25,5 \%$ & 2 & $1,9 \%$ & 1 & $0,9 \%$ & 106 & $100 \%$ \\
\hline 7 & 16 & $15,1 \%$ & 46 & $43,4 \%$ & 40 & $37,7 \%$ & 4 & $3,8 \%$ & 0 & $0 \%$ & 106 & $100 \%$ \\
\hline 8 & 29 & $27,4 \%$ & 57 & $53,8 \%$ & 18 & $17,0 \%$ & 2 & 1,95 & 0 & $0 \%$ & 106 & $100 \%$ \\
\hline 9 & 25 & $23,6 \%$ & 44 & $41,5 \%$ & 33 & $31,1 \%$ & 4 & $3,8 \%$ & 0 & $\%$ & 106 & $100 \%$ \\
\hline 10 & 35 & $33,0 \%$ & 57 & $53,8 \%$ & 14 & $13,2 \%$ & 0 & $0 \%$ & 0 & $\%$ & 106 & $100 \%$ \\
\hline
\end{tabular}

Sumber: Hasil Pengolahan Data SPSS (diolah) 2015

Tabel 2

Penyajian Data Variabel Stres Kerja (X1)

\begin{tabular}{|c|c|c|c|c|c|c|c|c|c|c|c|c|}
\hline \multirow{3}{*}{ No. } & \multicolumn{12}{|c|}{ Jawaban Responden } \\
\hline & \multicolumn{2}{|c|}{$\begin{array}{l}\text { Sangat } \\
\text { Setuju }\end{array}$} & \multicolumn{2}{|c|}{ Setuju } & \multicolumn{2}{|c|}{$\begin{array}{l}\text { Kurang } \\
\text { Setuju }\end{array}$} & \multicolumn{2}{|c|}{$\begin{array}{l}\text { Tidak } \\
\text { Setuju }\end{array}$} & \multicolumn{2}{|c|}{$\begin{array}{c}\text { Sangat } \\
\text { Tidak } \\
\text { Setuju }\end{array}$} & \multicolumn{2}{|c|}{ Junlah } \\
\hline & $\mathrm{F}$ & $\%$ & F & $\%$ & F & $\%$ & $\mathrm{~F}$ & $\%$ & $\mathrm{~F}$ & $\%$ & $\mathrm{~F}$ & $\%$ \\
\hline 1 & 10 & $9,4 \%$ & 32 & $30,2 \%$ & 39 & $36,8 \%$ & 20 & $18,9 \%$ & 5 & $4,7 \%$ & 106 & $100 \%$ \\
\hline 2 & 4 & $3,8 \%$ & 43 & $40,6 \%$ & 29 & $27,4 \%$ & 23 & $21,7 \%$ & 7 & $6,6 \%$ & 106 & $100 \%$ \\
\hline 3 & 4 & 3,8 & 21 & $19,8 \%$ & 38 & $35,8 \%$ & 19 & $17,9 \%$ & 24 & $22,6 \%$ & 106 & $100 \%$ \\
\hline 4 & 1 & $0,9 \%$ & 33 & $31,1 \%$ & 24 & $22,6 \%$ & 23 & $21,7 \%$ & 25 & $23,6 \%$ & 106 & $100 \%$ \\
\hline 5 & 10 & $9,4 \%$ & 46 & $43,4 \%$ & 28 & $26,4 \%$ & 15 & $14,2 \%$ & 7 & $6,6 \%$ & 106 & $100 \%$ \\
\hline 6 & 10 & $9,4 \%$ & 17 & $6,0 \%$ & 29 & $27,4 \%$ & 38 & $35,8 \%$ & 12 & $11,3 \%$ & 106 & $100 \%$ \\
\hline 7 & 2 & $1,9 \%$ & 25 & $23,6 \%$ & 25 & $23,6 \%$ & 26 & $24,5 \%$ & 28 & $26,4 \%$ & 106 & $100 \%$ \\
\hline 8 & 3 & $2,8 \%$ & 24 & $22,6 \%$ & 20 & $18,9 \%$ & 25 & $23,6 \%$ & 34 & $32,1 \%$ & 106 & $100 \%$ \\
\hline 9 & 7 & $6,6 \%$ & 31 & $29,2 \%$ & 14 & $13,2 \%$ & 32 & $30,2 \%$ & 22 & $20,8 \%$ & 106 & $100 \%$ \\
\hline 10 & 1 & $0,9 \%$ & 4 & $3,8 \%$ & 14 & $13,2 \%$ & 21 & $19,8 \%$ & 66 & $62,3 \%$ & 106 & $100 \%$ \\
\hline
\end{tabular}


Tabel 3

Penyajian Data Mengenai Variabel Pengembangan karir (X2)

\begin{tabular}{|c|c|c|c|c|c|c|c|c|c|c|c|c|}
\hline \multirow{3}{*}{ No. } & \multicolumn{12}{|c|}{ Jawaban Responden } \\
\hline & \multicolumn{2}{|c|}{$\begin{array}{l}\text { Sangat } \\
\text { Setuju }\end{array}$} & \multicolumn{2}{|c|}{ Setuju } & \multicolumn{2}{|c|}{$\begin{array}{c}\text { Kurang } \\
\text { Setuju }\end{array}$} & \multicolumn{2}{|c|}{$\begin{array}{l}\text { Tidak } \\
\text { Setuju }\end{array}$} & \multicolumn{2}{|c|}{$\begin{array}{l}\text { Sangat } \\
\text { Tidak } \\
\text { Setuju }\end{array}$} & \multicolumn{2}{|c|}{ Jumlah } \\
\hline & $\mathrm{F}$ & $\%$ & $\mathrm{~F}$ & $\%$ & $\mathrm{~F}$ & $\%$ & $\mathrm{~F}$ & $\%$ & $\mathrm{~F}$ & $\%$ & $\mathrm{~F}$ & $\%$ \\
\hline 1 & 2 & $1,9 \%$ & 26 & $24,5 \%$ & 58 & $54,7 \%$ & 16 & $15,1 \%$ & 4 & $3,8 \%$ & 106 & $100 \%$ \\
\hline 2 & 2 & $9 \%$ & 24 & $22,6 \%$ & 39 & $36,8 \%$ & 23 & $21,7 \%$ & 18 & $17,0 \%$ & 106 & $100 \%$ \\
\hline 3 & 11 & $10,4 \%$ & 59 & $55,7 \%$ & 26 & $4,5 \%$ & 9 & $8,5 \%$ & 1 & $0,9 \%$ & 106 & $100 \%$ \\
\hline 4 & 2 & & 23 & & 44 & & 24 & & 13 & & 106 & $100 \%$ \\
\hline 5 & 2 & & 16 &, $1 \%$ & 40 & $37,7 \%$ & 23 & $21,7 \%$ & 25 & $23,6 \%$ & 106 & $100 \%$ \\
\hline 6 & 12 & $11,3 \%$ & 68 & $64,2 \%$ & 20 & $18,9 \%$ & 5 & $4,7 \%$ & 1 & $0,9 \%$ & 106 & $100 \%$ \\
\hline 7 & 22 & $20,8 \%$ & 72 & $67,9 \%$ & 11 & $10,4 \%$ & 1 & $9 \%$ & 0 & $0 \%$ & 106 & $100 \%$ \\
\hline 8 & 22 & $20,8 \%$ & 36 & $34,0 \%$ & 43 & $40, \%$ & 1 & $0,9 \%$ & 0 & $0 \%$ & 106 & $100 \%$ \\
\hline 9 & 12 & $11,3 \%$ & 58 & $54,7 \%$ & 28 & $26,4 \%$ & 4 & $3,8 \%$ & 4 & $3,8 \%$ & 106 & $100 \%$ \\
\hline 10 & 49 & $46,5 \%$ & 42 & $39,6 \%$ & 8 & $7,5 \%$ & 4 & $3,8 \%$ & 3 & $2,8 \%$ & 106 & $100 \%$ \\
\hline
\end{tabular}

Sumber: Hasil Pengolahan Data SPSS (diolah) 2015

Tabel 4

Uji Normalitas Kolmogorov - Smirnov

One-Sample Kolmogorov-Smirnov Test

\begin{tabular}{|c|c|c|c|c|}
\hline & & $\begin{array}{l}\text { Stres } \\
\text { Kerja }\end{array}$ & $\begin{array}{c}\text { Pengembangan } \\
\text { Karir }\end{array}$ & $\begin{array}{c}\text { Prestasi } \\
\text { Kerja }\end{array}$ \\
\hline $\mathrm{N}$ & & 106 & 106 & 106 \\
\hline \multirow{2}{*}{$\begin{array}{l}\text { Normal } \\
\text { Parameters }^{a}\end{array}$} & Mean & 26.9623 & 34.1887 & 35.8774 \\
\hline & Std. Deviation & 8.38925 & 5.30429 & 6.09559 \\
\hline \multirow{3}{*}{$\begin{array}{l}\text { Most Extreme } \\
\text { Differences }\end{array}$} & Absolute & .119 & .132 & .097 \\
\hline & Positive & .110 & .132 & .097 \\
\hline & Negative & -.119 & -.103 & -.083 \\
\hline \multicolumn{2}{|c|}{ Kolmogorov-Smirnov Z } & 1.223 & 1.357 & .995 \\
\hline \multicolumn{2}{|c|}{ Asymp. Sig. (2-tailed) } & .100 & .050 & .275 \\
\hline
\end{tabular}

a. Test distribution is Normal.

Sumber : Data Penelitian (diolah) 2015

Tabel 5

Multikolinearitas

\begin{tabular}{|c|c|c|c|c|c|c|c|c|c|c|c|}
\hline \multicolumn{12}{|c|}{ Coefficients ${ }^{2}$} \\
\hline \multirow{2}{*}{\multicolumn{2}{|c|}{ Model }} & \multicolumn{2}{|c|}{$\begin{array}{c}\text { Unstandardiz } \\
\text { ed } \\
\text { Coefficients }\end{array}$} & \multirow{2}{*}{$\begin{array}{c}\begin{array}{c}\text { Standardized } \\
\text { Coefficients }\end{array} \\
\text { Beta } \\
\end{array}$} & \multirow[b]{2}{*}{$\mathrm{T}$} & \multirow[b]{2}{*}{ Sig. } & \multicolumn{3}{|c|}{ Correlations } & \multicolumn{2}{|c|}{$\begin{array}{c}\text { Collinearity } \\
\text { Statistics }\end{array}$} \\
\hline & & B & $\begin{array}{c}\text { Std. } \\
\text { Error }\end{array}$ & & & & $\begin{array}{l}\text { Zero- } \\
\text { order }\end{array}$ & Partial & Part & $\begin{array}{c}\text { Toleran } \\
\text { ce }\end{array}$ & VIF \\
\hline \multirow[t]{3}{*}{1} & (Constant) & $\begin{array}{r}19.25 \\
3\end{array}$ & 3.501 & & 5.500 & .000 & & & & & \\
\hline & Stres Kerja & -.256 & .047 & -.353 & -5.503 & .000 & -.755 & -.477 & -.262 & .550 & 1.818 \\
\hline & $\begin{array}{l}\text { Pengemban } \\
\text { gan Karir }\end{array}$ & .688 & .074 & .599 & 9.342 & .000 & .836 & .677 & .444 & .550 & 1.818 \\
\hline & pendent Var & le: $F$ & stasi F & Kerja & & & & & & & \\
\hline
\end{tabular}

Sumber : Data Penelitian (diolah) 2015 


\section{Analisis Data}

1. Uji Asumsi Klasik

Untuk menghasilkan suatu model yang baik, analisis regresi memerlukan pengujian asumsi klasik sebelum melakukan hipotesis. Apabila terjadi penyimpangan dalam pengujian asumsi klasik perlu dilakukan perbaikan terlebih dahulu. Pengujian asumsi klasik tersebut meliputi uji normalitas, uji multikolinearitas, dan uji heterokedastisitas.

a. Uji Normalitas

Pengujian normalitas data dilakukan untuk melihat apakah dalam model regresi variabel dependen dan independennya memiliki distribusi normal atau tidak. Dengan ketentuan pengujian jika data menyebar di sekitar garis diagonal dan mengikuti arah garis diagonal maka model regresi memenuhi asumsi normalitas. Berikut ini hasil uji normalitas untuk menguji keseluruhan data yang berskala minimal ordinal maka digunakan uji Kolmogrov-smirnov.

Berdasarkan data tabel uji normalitas diatas dapat dilihat bahwa data dalam penelitian ini berdistribusi normal. Suatu data dikatakan terdistribusi secara normal apabila memiliki nilai uji kolmogrov Asymp.Sig lebih besar dari 0,05. Untuk lebih jelasnya dapat dilihat pada gambar normal $P-P$ plot of regression standardized residual pada gambar di bawah ini:

$$
\text { Normal P.P Plot of Regression Standardized Residual }
$$

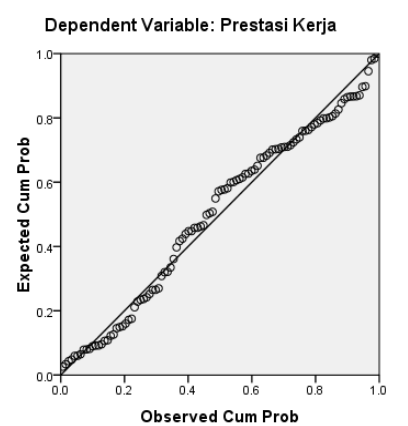

Gambar 2. Uji Normalitas P-P Plot Standardized

Gambar PP Plot standardized di atas mengindikasikan bahwa pengujian normalitas model regresi pada penelitian ini telah memenuhi asumsi yang telah dikemukakan sebelumnya, sehingga data dalam model regresi penelitian ini cenderung normal atau merapat ke garis. b. Uji Multikolinearitas

Perhitungan uji independen antar variabel bebas dapat dilihat dan hasil analisis collinearty statistis. Untuk melihat apakah diantara variabel tidak terjadi korelasi tinggi, perlu dilakukan hipotesis yaitu bahwa diterima Ho apabila nilai VIF $<10$ dan angka toleransi mendekati 1, dan ditolak Ho bila nilai VIF $>10$ dan nilai toleransi mendekati 0 .

Berdasarkan data tabel uji multikolinieritas di atas dapat dipahami bahwa kedua variabel independen yakni Stres kerja $\left(\mathrm{X}_{1}\right)$ dan pengembangan karir $\left(\mathrm{X}_{2}\right)$ memiliki nilai VIF 1.818 dalam batas toleransi yang telah ditentukan dimana semua variabel mendekati angka 1 dan nilai VIF lebih kecil dari 10, sehingga dengan demikian tidak terjadi multikolinearitas dalam variabel independen pada penelitian ini.

\section{c. Uji Heterokedastisitas}

Pengujian heterokedastisitas ini digunakan untuk melihat apakah variabel dependent mempunyai varian yang sama atau tidak. Heteroskedatisitas mempunyai suatu pengamatan ke pengamatan yang lain berbeda. Salah satu metode yang digunakan untuk menguji ada tidaknya heteroskedastisitas akan mengakibatkan penaksiran koefesienkoefesien regresi menjadi tidak efesien. Hasil penaksiran akan menjadi kurang dari semestinya. Dasar analisis penilaian data heterokedastisitas adalah sebagai berikut:

- Jika ada pola tertentu, seperti titik-titik yang ada membentuk pola tertentu yang teratur (bergelombang kemudian menyempit) maka mengindikasikan telah terjadi heteroskedastisitas

- Jika ada pola yang jelas, serta titik-titik menyebar di atas dan di bawah angka 0 pada sumbu Y, maka tidak terjadi Heteroskedastisitas.

Berdasarkan Gambar "Scatterplot" di bawah dapat dipahami bahwa tidak terjadi heteroskedatisitas, sebab tidak ada pola yang jelas serta titiktitik menyebar di atas dan di bawah angka 0 pada sumbu Y. Sehingga dapat dikatakan uji heteroskedastisitas terpenuhi. 
Scatterplot

Dependent Variable : Prestasi kerja

Scatterplot

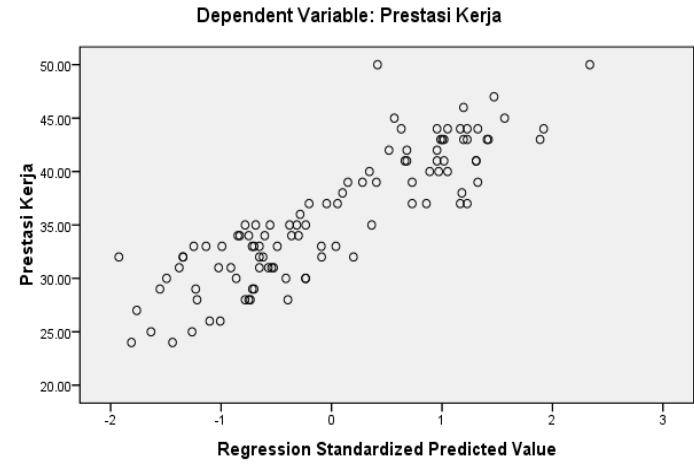

Gambar 3. Scatterplot Uji Heterokedastisitas

\section{Analisis Regresi Berganda}

Analisis data dalam penelitian ini menggunakan analisis linear berganda. Dalam penelitian ini terdapat dua variabel independen, yaitu stres kerja dan pengembangan karir, serta satu variabel dependen yaitu prestasi. Adapun rumus linear berganda adalah sebagai berikut :

$$
Y=a+b_{1} x_{1}+b_{2} x_{2}
$$

Dari Tabel 6, pada kolom Standardized Coefficients), dapat dilihat persamaan regresi ganda untuk dua predictor (stres kerja dan pengembangan karir) adalah :

$$
Y=a+b_{1} x_{1}+b_{2} x_{2}+e
$$

maka diperoleh nilai

$$
Y=19,253+-0,256 X_{1}+0,688 X_{2}
$$

Persamaan di atas memperlihatkan bahwa variabel Stres kerja memiliki koefisien yang negatif, dengan demikian dapat dipahami bahwa variabel $\mathrm{X}_{1}$ (stres kerja) tidak terdapat pengaruh searah terhadap variabel Y (prestasi kerja), sedangkan variabel $\mathrm{X}_{2}$ pengembangan karir memiliki koefisien positif, berarti variabel bebas $\mathrm{X}_{2}$ mempunyai pengaruh yang searah terhadap variabel Y (prestasi kerja). Koefisien stres kerja memberikan nilai sebesar -0,256 yang berarti bahwa jika nilai stres kerja semakin naik maka prestasi kerja akan mengalami penurunan. Begitu juga dengan koefisien pengembangan karir memberikan nilai sebesar 0,688 yang berarti bahwa pengembangan karir semakin baik dengan asumsi lain tetap, maka prestasi kerja juga akan mengalami peningkatan.

\section{Uji Secara Parsial (Uji t)}

Uji statistik t pada dasarnya bertujuan untuk menunjukkan seberapa jauh pengaruh satu variabel independen secara individual dalam menerangkan variabel dependen. Dengan bantuan Program Statistical for Social Sciences (SPSS).

a. Pengaruh Stres Kerja Terhadap Prestasi Kerja Dari data Tabel 7 (uji t) dapat diketahui:

$$
\begin{array}{ll}
\mathrm{t}_{\text {hitung }} & =-5.503 \\
\mathrm{t}_{\text {tabel }} & =1.983 \text { (data terlampir) }
\end{array}
$$

Kriteria pengambilan keputusan :

$\mathrm{H}_{0}$ ditolak bila : Bila $\mathrm{t}_{\text {hitung }}>\mathrm{t}_{\text {tabel }}$ atau $-\mathrm{t}_{\text {hitung }}<-\mathrm{t}_{\text {tabel }}$ pada $\alpha=5 \%$

$\mathrm{H}_{0}$ diterima bila : Bila $\mathrm{t}_{\text {hitung }} \leq \mathrm{t}_{\text {tabel }}$ atau $-\mathrm{t}_{\text {hitung }} \geq-$ $\mathrm{t}_{\text {tabel }}$

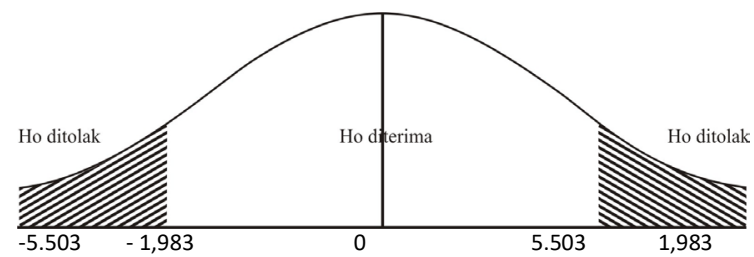

Gambar 4. Kriteria Pengujian Hipotesis

Berdasarkan hasil pengujian di atas pengaruh antara stres kerja (X1) terhadap prestasi kerja pegawai di peroleh t tabel sebesar -1.983 (data $\mathrm{t}_{\text {tabel }}$ terlampir), dan $\mathrm{t}_{\text {hitung }}$ sebesar $-5.503 \mathrm{t}_{\text {hitung }}<$ $\mathrm{t}_{\text {tabel }}$ dari hasil tersebut dapat disimpulkan bahwa Ho diterima. Hal ini menunjukkan bahwa tidak ada pengaruh antara stres kerja terhadap prestasi kerja Karyawan pada PT. Jasa Marga (Persero) Tbk, Cabang Belmera.

b. Pengaruh Pengembangan Karir Terhadap Prestasi Kerja

Dari data Tabel 8 di atas diketahui:

$$
\begin{aligned}
& \mathrm{t}_{\text {hitung }}=9,342 \\
& \mathrm{t}_{\text {tabel }}=1.983 \text { (data terlampir) }
\end{aligned}
$$


Tabel 6

Regresi Linear Berganda

\begin{tabular}{|c|c|c|c|c|c|c|}
\hline & & \multicolumn{2}{|c|}{$\begin{array}{c}\text { Unstandardized } \\
\text { Coefficients }\end{array}$} & \multirow{2}{*}{$\begin{array}{c}\text { Standardized } \\
\text { Coefficients } \\
\text { Beta }\end{array}$} & \multirow[b]{2}{*}{$\mathrm{T}$} & \multirow[b]{2}{*}{ Sig. } \\
\hline \multicolumn{2}{|c|}{ Model } & B & $\begin{array}{l}\text { Std. } \\
\text { Error }\end{array}$ & & & \\
\hline \multirow[t]{3}{*}{1} & (Constant) & 19.253 & 3.501 & & 5.500 & .000 \\
\hline & Stres Kerja & -.256 & .047 & -.353 & -5.503 & .000 \\
\hline & $\begin{array}{l}\text { Pengembangan } \\
\text { Karir }\end{array}$ & .688 & .074 & .599 & 9.342 & .000 \\
\hline & pendent Variab & restas & $\overline{e r j a}$ & & & \\
\hline
\end{tabular}

Sumber: Hasil Pengolahan Data SPSS (diolah) 2015

Tabel 7

Uji t

Coefficients

\begin{tabular}{|c|c|c|c|c|c|c|}
\hline \multirow{2}{*}{\multicolumn{2}{|c|}{ Model }} & \multicolumn{2}{|c|}{$\begin{array}{l}\text { Unstandardized } \\
\text { Coefficients }\end{array}$} & \multirow{2}{*}{$\begin{array}{c}\begin{array}{c}\text { Standardized } \\
\text { Coefficients }\end{array} \\
\text { Beta }\end{array}$} & \multirow[b]{2}{*}{$\mathbf{T}$} & \multirow[b]{2}{*}{ Sig. } \\
\hline & & B & Std. Error & & & \\
\hline \multirow[t]{3}{*}{1} & (Constant) & 19.253 & 3.501 & & 5.500 & .000 \\
\hline & Stres Kerja & -.256 & .047 & -.353 & -5.503 & .000 \\
\hline & Pengembangan Karir & .688 & .074 & .599 & 9.342 & .000 \\
\hline
\end{tabular}

a. Dependent Variable: Prestasi Kerja

Sumber: Hasil Pengolahan Data SPSS (diolah) 2015

Tabel 8

Uji t

Coefficients $^{a}$

\begin{tabular}{|c|c|c|c|c|c|c|}
\hline \multirow{2}{*}{\multicolumn{2}{|c|}{ Model }} & \multicolumn{2}{|c|}{$\begin{array}{l}\text { Unstandardized } \\
\text { Coefficients }\end{array}$} & \multirow{2}{*}{$\begin{array}{c}\text { Standardized } \\
\text { Coefficients } \\
\text { Beta } \\
\end{array}$} & \multirow[b]{2}{*}{$\mathbf{T}$} & \multirow[b]{2}{*}{ Sig. } \\
\hline & & B & Std. Error & & & \\
\hline \multirow[t]{3}{*}{1} & (Constant) & 19.253 & 3.501 & & 5.500 & .000 \\
\hline & Stres Kerja & -.256 & .047 & -.353 & -5.503 & .000 \\
\hline & Pengembangan Karir & .688 & .074 & .599 & 9.342 & .000 \\
\hline
\end{tabular}

a. Dependent Variable: Prestasi Kerja

Sumber: Hasil Pengolahan Data SPSS (diolah) 2015

Tabel 9

Uji F

ANOVA $^{\text {b }}$

\begin{tabular}{llrrrrr}
\hline Model & $\begin{array}{c}\text { Sum of } \\
\text { Squares }\end{array}$ & Df & $\begin{array}{c}\text { Mean } \\
\text { Square }\end{array}$ & \multicolumn{1}{c}{ F } & Sig. \\
\hline \multirow{2}{*}{1} & 2992.490 & 2 & 1496.245 & 169.557 & $.000^{\mathrm{a}}$ \\
\cline { 2 - 7 } & Regression & 908.916 & 103 & 8.824 & & \\
\cline { 2 - 7 } & Residual & 3901.406 & 105 & & & \\
\hline Total & &
\end{tabular}

a. Predictors: (Constant), Pengembangan Karir, Stres Kerja

b. Dependent Variable: Prestasi Kerja

Sumber: Hasil Pengolahan Data SPSS (diolah). 2015

Tabel 10

Koefisien Determinasi

Model Summary ${ }^{b}$

\begin{tabular}{llrrrr}
\hline Model & $\mathbf{R}$ & R Square & $\begin{array}{c}\text { Adjusted R } \\
\text { Square }\end{array}$ & $\begin{array}{l}\text { Std. Error of } \\
\text { the Estimate }\end{array}$ & Durbin-Watson \\
\hline 1 & $.876^{\mathrm{a}}$ & .767 & .763 & 2.97059 & 1.600 \\
\hline
\end{tabular}

a. Predictors: (Constant), Pengembangan Karir, Stres Kerja

b. Dependent Variable: Prestasi Kerja

Sumber: Hasil Pengolahan Data SPSS (diolah) 2015 
Kriteria pengambilan keputusan :

$\mathrm{H}_{0}$ ditolak bila : Bila $\mathrm{t}_{\text {hitung }}>\mathrm{t}_{\text {tabel }}$ atau $-\mathrm{t}_{\text {hitung }}$ $<-\mathrm{t}_{\text {tabel }}$ pada $\alpha=5 \%$

$\mathrm{H}_{0}$ diterima bila : Bila $\mathrm{t}_{\text {hitung }} \leq \mathrm{t}_{\text {tabel }}$ atau $-\mathrm{t}_{\text {hitung }}$ $\geq-\mathrm{t}_{\text {tabel }}$

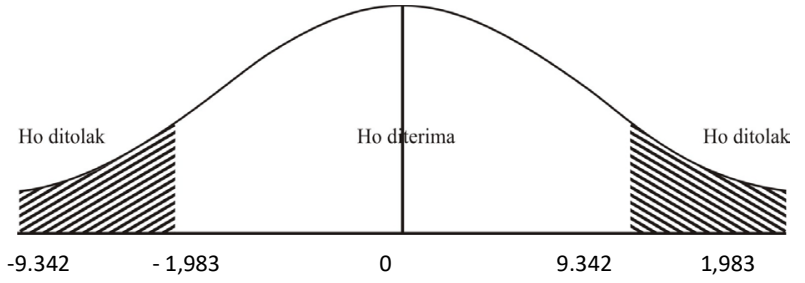

Gambar 5. Kriteria Pengujian Hipotesis

Berdasarkan hasil pengujian di atas pengaruh antara Pengembangan Karir $\left(\mathrm{X}^{2}\right)$ terhadap Prestasi Kerja di peroleh $t_{\text {tabel }}$ sebesar 1.983, dan $t_{\text {hitung }}$ sebesar 9,342 $t_{\text {hitung }}>t_{\text {tabel }}$ dari hasil tersebut dapat disimpulkan bahwa Ho ditolak. Hal ini menunjukkan bahwa adanya pengaruh signifikan antara pengembangan karir dengan prestasi kerja karyawan pada PT. Jasa Marga (Persero) Tbk. Cabang Belmera

\section{Uji F}

Uji statistik F (simultan) dilakukan untuk mengetahui apakah variabel bebas (independen) secara bersama-sama berpengaruh secara signifikan atau tidak terhadap variabel terikat (dependen). Selanjutnya hipotesis tersebut dikonversi ke dalam hipotesis statistik sebagai berikut :

H0 $: \rho=0$ (Tidak ada pengaruh antara stres kerja

$\left(\mathrm{X}_{1}\right)$ dan pengembangan karir $\left(\mathrm{X}_{2}\right)$ terhadap prestasi kerja karyawan.

H0 : $\rho \neq 0$ (Ada pengaruh antara stres kerja $\left(X_{1}\right)$ dan pengembangan karir $\left(\mathrm{X}_{2}\right)$ terhadap kprestasi kerja karyawan.

Kriteria Hipotesis :

- Tolak $\mathrm{H}_{0}$ jika nilai $\mathrm{F}_{\text {hitung }} \geq \mathrm{F}_{\text {tabel }}$ taraf signifikan sebesar 0,05 .

- Terima $\mathrm{H}_{0}$ jika nilai $\mathrm{F}_{\text {hitung }}<\mathrm{F}_{\text {tabel }}$ taraf signifikan sebesar 0,05 .

Kriteria penilaian hipotesis:

- $\mathrm{F}_{\text {hitung }}>\mathrm{F}_{\text {tabel }}=\mathrm{H} 0$ ditolak, taraf signifikan sebesar 0,05 (sig.2-tailed $\leq 0,05)$

- $\mathrm{F}_{\text {hitung }}<\mathrm{F}_{\text {tabel }}=$ Ha diterima, taraf signifikan sebesar 0,05 (sig.2-tailed $\geq 0,05$ )

Berdasarkan data Tabel 9 (uji f) dengan kriteria di atas diperoleh nilai $\mathrm{F}_{\text {hitung }}$ sebesar 169,557, sedangkan nilai $\mathrm{F}_{\text {tabel }}$ 3,085 atau signifikan $\mathrm{F}_{\text {hitung }}$ $0.00<0.05$ sehingga dapat dipahami bahwa terdapat pengaruh signifikan antara variabel bebas ( Stres Kerja $\mathrm{X}_{1}$ dan Pengembangan Karir $\mathrm{X}_{2}$ ) terhadap variabel terikat Y (Prestasi Kerja).

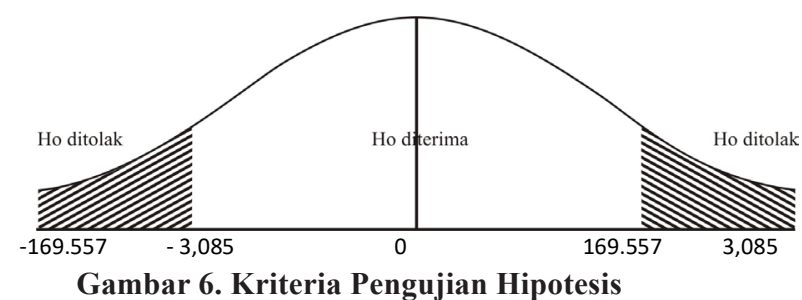

Berdasarkan tabel uji hipotesis di atas dapat diketahui bahwa nilai $\mathrm{F}_{\text {hitung }}$ adalah dengan tingkat signifikan 169,557, sedangkan $\mathrm{F}_{\text {tabel }}$ sebesar 3,085 dengan tingkat signifikan 0,05. Berdasarkan nilai kurva tersebut di atas dapat dipahami bahwa terdapat pengaruh yang signifikan antara variabel stres kerja dan pengembangan karir terhadap prestasi kerja.

\section{Koefisien Determinasi}

Koefisien determinasi merupakan besaran yang menunjukkan besarnya variasi variabel dependen yang dapat dijelaskan oleh variabel independennya. Dengan kata lain, koefisien determinasi ini digunakan untuk mengukur seberapa jauh variabel variabel bebas dalam menerangkan variabel terikatnya. Nilai koefisien determinasi ditentukan dengan nilai $R$ square sebagaimana dapat dilihat pada Tabel 10 .

Berdasarkan hasil perhitungan regresi pada Tabel 10 dapat diketahui bahwa koefisien determinasi ( $R$ square) yang diperoleh sebesar 0,767. Hal ini berarti 76,7 \% variabel prestasi kerja dapat dijelaskan oleh variabel pengembangan karir dan stres kerja, sedangkan sisanya sebesar 23,3\% diterangkan oleh variabel lain yang tidak diteliti.

\section{PEMBAHASAN}

Data penelitian akan dijabarkan melalui hipotesis dari penelitian berdasarkan analisis data. Lebih rinci hasil analisis dan pengujian tersebut 
dapat dijelaskan sebagai berikut :

1. Pengaruh Stres Kerja terhadap Prestasi Kerja Stres merupakan suatu masalah yang pasti akan dihadapi oleh setiap orang dalam kehidupan berkarya. Stres dapat timbul sebagai akibat tekanan atau ketegangan yang bersumber dari ketidak selarasan antara seseorang dengan lingkungannya. Oleh karena itu bahwa stres yang tidak teratasi pasti berpengaruh terhadap prestasi kerja.

Berdasarkan hasil pengujian terhadap variabel stres kerja (X1) terhadap prestsi kerja karyawan di peroleh $t$ tabel sebesar 1.983 (data $t_{\text {tabe }}$ terlampir), dan $\mathrm{t}_{\text {hitung }}$ sebesar $-5.503 \mathrm{t}_{\text {hitung }}<\mathrm{t}_{\text {tabel }}$ dari hasil tersebut dapat disimpulkan bahwa Ho diterima. Hal ini menunjukkan bahwa adanya pengaruh antara stres kerja terhadap prestasi kerja karyawan pada PT. Jasa Marga (Persero) Tbk. Cabang Belmera.

Hasil penelitian ini tidak sejalan dengan teori yang dikemukakan oleh Handoko (2014, hal. 193) "banyak faktor yang dapat mempengaruhi prestasi kerja antara lain: motivasi, kepuasan kerja, tingkat stres, dan kondisi fisik." Juga tidak sejalan dengan penelitian yang dikemukakan oleh Hesti Suprihatiningrum, 2001. STIE Widya Mangala Semarang yang mengatakan ada pengaruh yang signifikan antara stres kerja terhadap prestasi kerja.

2. Pengaruh Pengembangan Karir Terhadap Prestasi Kerja

Karir merupakan seluruh pekerjaan yang dipegangnya selama ia bekerja. Untuk sebagian orang, pekerjaan/kedudukan tersebuat merupakan bagian dari rencananya.Pengembangan karir dimulai dari diri sendiri. Setiap orang harus menerima tanggung jawab pengembangan karirnya sendiri, setelah komitmen dibuat barulah aksi pengembangan karir dilakukan untuk meningkatkan prestasi kerja karyawan tersebut.

Berdasarkan hasil pengujian secara parsial pengaruh antara pengembangan karir terhadap prestasi kerja di peroleh hasil uji t tabel sebesar 1.983 (data $t_{\text {tabel }}$ terlampir), dan $t_{\text {hitung }}$ sebesar 9,342 $\mathrm{t}_{\text {hitung }}>\mathrm{t}_{\text {tabel }}$ dari hasil tersebut dapat disimpulkan bahwa Ho ditolak. Hal ini menunjukkan bahwa adanya pengaruh signifikan antara pengembangan karir dengan prestasi kerja
Karyawan pada PT. Jasa Marga (Persero) Tbk, Cabang Belmera berate bahwa semakin makin baik pengembangan karir yang dilakukan akan semakin baik pula prestasi kerja karyawan.

Hasil penelitian ini sejalan dengan teori yang dikemukakan oleh Mangkunegara (2013, hal. 77) mengemukakan bahwa pengembangan karir adalah aktivitas kepegawaian yang membantu pegawai-pegawai merencanakan karir masa depan mereka di perusahaan agar perusahaan dan pegawai yang bersangkutan dapat mengembangkan diri secara maksimum.

Hasil penelitian ini sejalan dengan penelitian terdahulu yang dikemukakan oleh Dwi Wahyuni, dkk 2014. Jurnal administrasi Bisnis FIA Universitas Brawijaya yang mengatakan bahwa ada pengaruh yang signifikan antara pengembangan karir terhadap prestasi kerja.

3. Pengaruh Stres Dan Pengembangan Karir Terhadap Prestasi Kerja

Pengembangan karir merupakan proses peningkatan kemampuan kerja seseorang yang mendorong adanya peningkatan prestasi kerja dalam rangka mencapai karier yang didukung oleh perusahaan. Maka dengan demikian perusahaan mengharapkan adanya timbal balik dari karyawan yaitu berupa prestasi kerja.

Berdasarkan hasil uji secara simultan uji $\mathrm{f}$ diperoleh nilai $\mathrm{F}_{\text {hitung }}$ sebesar 169,557, sedangkan nilai $\mathrm{F}_{\text {tabel }} 3,085$ atau signifikan $\mathrm{F}_{\text {hitung }} 0.00<$ 0.05 sehingga dapat dipahami bahwa terdapat pengaruh signifikan antara variabel bebas ( Stres Kerja $X_{1}$ dan Pengembangan Karir $X_{2}$ ) terhadap variabel terikat Y (Prestasi Kerja). Berarti bahwa jika stres karyawan semakin tinggi maka prestasi karyawan akan menurun sedangkan jika pengembangan karir karyawan semakin baik maka semakin baik pula prestasi seorang karyawan sedangkan $R$-Square diperoleh 0,767 hal ini berarti $79,7 \%$ variabel prestasi kerja dapat dijelaskan oleh variabel stres kerja dan variabel pengembangan karir, sedangkan sisanya sebesar 23,\% diterangkan oleh variabel lain yang tidak teliti.

Menurut Panji Anoraga (2009, hal. 113) menyatakan bahwa stres terjadi dalam komponenkomponen fisik. Pekerjaan atau lingkungan sosial pekerjaan biasanya dapat mengakibatkan ketegangan pada manusia, baik karena sebab sebab 
yang rumit ataupun yang sederhana, menunjuk- Terhadap Prestasi Kerja Karyawan Pada PT. Jasa kan bahwa unsur-unsur tertentu seperti suara Marga (Persero) Tbk, maka penulis mengambil gaduh, suhu udara yang tinggi atau terlalu rendah kesimpulan sebagai berikut:

dan banyak kondisi penghambat lain mempun- 1. Berdasarkan hasil pengujian pengaruh antara yai kemungkinan yang tak terelakkan sebagai stres kerja (X1) terhadap prestasi kerja karpenyebab stres akan muncul dan pada gilirannya perasaan tidak puas akan sedikit banyak mempengaruhi prestasi kerja. yawan di peroleh $\mathrm{t}$ tabel sebesar -1.983 , dan $\mathrm{t}_{\mathrm{hi}}$ tung sebesar $-5.503 \mathrm{t}_{\text {hitung }}>\mathrm{t}_{\text {tabel }}$ dari hasil tersebut dapat disimpulkan bahwa Ho diterima.

Menurut Kartana dalam Sutrisno (2009, hal. 2. Berdasarkan hasil pengujian pengaruh antara 176) mengemukakan untuk mengembangkan kaPengembangan Karir $\left(\mathrm{X}^{2}\right)$ terhadap Prestasi rir harus selalu memfokuskan segala daya dan kemampuan pada cita-cita atau rujukan yang ingin dicapai. Ini dilakukan karena suatu rujukan meruKerja di peroleh $t$ tabel sebesar 1.983 , dan $t_{\text {hi- }}$ tung sebesar 9,342 $\mathrm{t}_{\text {hitung }}>\mathrm{t}_{\text {tabel }}$ dari hasil tersebut dapat disimpulkan bahwa Ho ditolak.

pakan alat motivator yang paling dominan bagi 3 . Berdasarkan hasil uji $\mathrm{f}$ secara simultan dipersetiap orang untuk mencapai prestasi.

oleh nilai $\mathrm{F}_{\text {hitung }}$ sebesar 169,557 , sedangkan nilai $\mathrm{F}_{\text {tabel }} 3,085$ atau signifikan $\mathrm{F}_{\text {hitung }} 0.00<$ 0.05 sehingga dapat dipahami bahwa terdapat pengaruh signifikan antara variabel bebas (

Hasil penelitian dan pembahasan tentang Stres Kerja $\mathrm{X}_{1}$ dan Pengembangan Karir $\mathrm{X}_{2}$ ) Pengaruh Stress Kerja dan Pengembangan Karir terhadap variabel terikat $\mathrm{Y}$ (Prestasi Kerja). 


\section{REFERENSI}

Anoraga, Panji. (2009). Psikologi Kerja. Rineka Cipta.

Dwi Wahyuni dkk. Pengaruh Pengembangan Karir Terhadap Prestasi Kerja Karyawan (Studi pada Karyawan Tetap PT. Astra Internasional, Tbk Daihatsu Malang). Jurnal Administrasi Bisnis (JAB). Universitas Brawijaya. 2014.

Handoko, Hani, T. (2014). Manajemen Personalia dan Sumber Daya Manusia. Edisi kedua. Cetakan keduapuluh Satu. BPFE : Yogyakarta.

Hasibuan, SP, Malayu. (2013). Manajemen sumber daya manusia. Cetakan Ketujuh Belas. PT Bumi Aksara.

Hawari, Dadang. (2013). Manajemen Stres, Cemas dan Depresi, Edisi kedua Cetakan Keempat. FKUI: Jakarta.

Hesti Supriha Tiningrum dkk. Faktor - faktor yang Mempengaruhi Prestasi Kerja (Studi Pada Karyawan Kantor Kementrian Agama Provinsi Jawa Tengah). Jurnal Administasi Bisnis. Sekolah Tinggi Ilmu Ekonomi Widya Manggala. 2013

Juliandi, Azuar dan Irfan. (2014). Metodologi penelitian kuantitatif. Cetakan Kedua. Citapustaka Media Perintis.

Prabu, Anwar. (2013). Manajemen Sumber Daya Manusia Perusahaan. Cetakan Kesebelas. PT Remaja Rosdakarya.

Siagian, P, Sondang. (2008). Manajemen Sumber Daya Manusia. Cetakan Kelima Belas. PT Bumi aksara.

Sugiyono. (2008). Metode Penelitian Bisnis. Cetakan keduabelas. Alfabeta : Bandung

Sutrisno, Edy. (2012). Manajemen Sumber Daya Manusia. Cetakan Keempat. Kencana.

Yani, M. (2012). Manajemen Sumber Daya Manusia. Mitra Wacana Media. 
